\title{
DiVERSIDADE CULTURAL NO ESPAÇO ESCOLAR: IMPLICAÇÓES NO ENSINO, NA APRENDIZAGEM E NOS PROCESSOS DE SUBJETIVAÇÁO
}

\author{
CULTURAL DIVERSITY IN SCHOOL SPACE: IMPLICATIONS FOR \\ TEACHING, LEARNING AND SUBJECTIVATION PROCESSES
}

\author{
Elaine Teresinha Dal Mas Dias \\ Doutorado em Psicologia pela Universidade de São Paulo \\ Professora do Programa de Pós-Graduaçáo em Educaçáo da Uni- \\ versidade Nove de Julho. São Paulo - SP - Brasil \\ ORCID: https://orcid.org/0000-0002-4383-5847 \\ elaine.mas@uni9.pro.br
}

\begin{abstract}
João Clemente de Souza Neto
Doutorado em Ciências Sociais pela Pontifícia Universidade Católica de São Paulo. Professor do Programa de Pós-Graduação em Educação, Artes e História da cultura e do Curso de Pedagogia da Universidade Presbiteriana Mackenzie. Membro do Instituto Catequético Secular São José da Pastoral do Menor da Região Episcopal Lapa. São Paulo - SP - Brasil ORCID: https://orcid.org/0000-0003-3348-8316)

joao.souza@mackenzie.br
\end{abstract}

Resumo: Esta pesquisa analisa relaçóes interpessoais e educativas entre docentes e alunos(as) imigrantes bolivianos(as), descendentes de bolivianos(as) e náo bolivianos(as) em sala de aula, nas dependências de uma escola pública do Ensino Fundamental II, no município de São Paulo. Teve como objetivos verificar o cumprimento dos Parâmetros Curriculares Nacionais, do Estatuto da Criança e do Adolescente, da Declaraçáo Universal sobre a Diversidade Cultural e da Lei de Migração, e identificar a ocorrência de negligência, discriminação e/ou opressão. Os procedimentos metodológicos adotados foram a observação e o registro sistemático da atuação de dois professores colaboradores das turmas de $8^{\circ}$ e $9^{\circ}$ anos de reunióes de Hora de Trabalho Pedagógico Coletivo, de pais e de áreas comuns. Pôde-se observar que os docentes e o alunado sofrem a interferência de aspectos subjetivos preconceituosos e discriminadores que impedem uma convivência harmônica entre imigrantes e descendentes e não imigrantes, com reflexos no seu crescimento pessoal e escolar. Nossa conclusão é de que a instituição escolar se mostra em descompasso com a legislação vigente.

Palavras-chave: Imigrantes Bolivianos. Educação. Preconceito. Subjetividade.

Aвstract: The present research focuses interpersonal and educational relationship between teachers and immigrants Bolivians, descended from Bolivians and non-Bolivian students inside the classroom, at a public Elementary School in São Paulo city, which purpose was to verify the fulfillment of National Curricular Parameters, Child and Adolescent Statute (ECA), Universal Declaration on Cultural Diversity and the Migration 
Law, to identify negligence, discrimination and/or oppression occurrence. The adopted methodological procedures were the observation and the systematic registration of two teachers work in their grades 8 and 9, including meetings at the Collective Pedagogical Work Time, parents' meetings and common areas at school. It was possible to note that the teachers and students are affected by prejudiced and discriminatory subjective aspects which interfere and block the harmony between immigrants, descended and non-immigrants, impacting their personal and educational growth. We conclude that the educational institution is in disagreement with the current law.

KeYwords: Immigrants Bolivians. Education. Prejudice. Subjectivity.

\section{Introdução}

Êxodos voluntários e involuntários sempre estiveram presentes nas sociedades humanas, em decorrência de guerras, conformação de novos estados, revoltas civis, golpes políticos, violaçôes dos direitos humanos, busca por estudo e trabalho. Essa realidade impóe-se como um tema candente desde o início de século XXI diante da avalanche de refugiados que abandonam seus países por diferentes motivos.

No período compreendido entre 1810 e 1979 os aportados eram, sobretudo, de origem europeia. Destacavam-se os portugueses, com percentual de imigrantes ${ }^{1}$ aproximado de $31,9 \%$, os italianos com $29,0 \%$, e os espanhóis com $11,1 \%$. No final do século XIX e início do XX houve um avanço numérico de italianos e a chegada de japoneses ao longo da Segunda Guerra Mundial (FERNANDES, 2015). A temática das migraçôes ganhou corpo na legislaçáo brasileira em dezembro de 1820, com o Decreto $\mathrm{n}^{\circ} .2$ e a exigência de passaporte para ingresso no país. O primeiro Estatuto do Estrangeiro, sob n. 3.010, foi promulgado em 1938; o segundo, Decreto-lei n. 7.967, em 1945; o terceiro, Decreto-lei n. 941, de 1969, pautava-se na Doutrina de Segurança Nacional resultante do processo ditatorial vivenciado a partir de 1964; o quarto, Lei n. 6.815, é de 1980 (CLARO, 2015). O intuito da legislação era inibir o acesso de pessoas desprovidas de posses ou de capacidades profissionais específicas, em particular as provenientes da África e da América Latina (ALVES, 2011), e criminalizar os indocumentados. Por outro viés, a lógica da Lei de Migração n. 13.445, promulgada em 2017, é a integração e a assimilaçáo orgânica do migrante aos sistemas sociocultural, educacional, econômico e jurídico do país. 
Nesse aspecto, essa lei rompe com o caráter nacionalista do Estatuto do Migrante, que considera os imigrantes cidadãos de segunda classe, exceto os portugueses, e garante ao migrante a acolhida humanitária, o "acesso igualitário e livre a serviços, programas e benefícios sociais, bens públicos, educação, assistência jurídica integral pública, moradia, serviço bancário e seguridade social", como recomendado pelo seu art. $3^{\circ}$ do capítulo I das Disposiçốes Preliminares, Seção I, Disposiçôes Gerais, concentrando-se no respeito e em sua aceitação, integração e acolhimento incondicional, a saber:

I - universalidade, indivisibilidade e interdependência dos direitos humanos;

II - repúdio e prevenção à xenofobia, ao racismo e a quaisquer formas de discriminação;

III - não criminalização da migração;

IV - não discriminação em razão dos critérios ou dos procedimentos pelos quais a pessoa foi admitida em território nacional; $\mathrm{V}$ - promoçáo de entrada regular e de regularizaçáo documental; VI - acolhida humanitária; (D.O.U., 2017, p.1)

Portanto, a igualdade no tratamento e de oportunidades aos migrantes e seus familiares passou a fazer parte dos princípios e diretrizes que regem a nova política migratória do país, em conformidade com a política internacional de Direitos Humanos. Foge, portanto, à observância da Lei n. 13.445 qualquer referência a ato discriminatório, de xenofobia ou racismo.

A multiplicidade de culturas europeias, associadas às indígenas e africanas, nos momentos iniciais da colonização determinou uma miscigenação importante, mas não livrou a população brasileira de revelar-se assimilacionista nem despertou nela uma cultura de multiculturalismo. Pelo contrário, fortaleceu no país o processo de assimilação de outras culturas pelo ângulo de uma matriz colonizadora (DIAS; SOUZA NETO, 2018), haja vista os atos discriminatórios e preconceituosos promotores de conflitos e tensôes decorrentes de intolerâncias e inflexibilidades emanadas de convivências nada integradoras.

Cada nova lei é expressão das múltiplas lutas em prol da garantia dos direitos humanos e da consolidação da democracia, na qual cada 
pessoa vai encontrando seu jeito de se colocar no mundo e de viver dentro da diversidade e na perspectiva de um mundo plural. As leis e os diferentes processos de argumentação não eliminam as contradiçôes e os paradoxos, mas colocam essa temática em outro patamar. Mais do que uma questão de leis, é de convivência humana, ambas questóes ocorrendo no campo relacional.

Assim sendo, reforçam-se as dúvidas quanto à formação escolar de crianças e adolescentes, em especial no tocante à construção de conhecimentos éticos dirigidos às diferenças, aqui voltados aos alunos imigrantes de origem boliviana. Portanto, indaga-se: os alunos bolivianos ou descendentes de bolivianos sofrem algum tipo de negligência ou opressão na escola? São respeitados e respeitam docentes e a comunidade escolar? Como se comportam em sala de aula e nas dependências comuns? $O$ processo de aprendizagem é satisfatório? As obrigações ou atividades são realizadas ou há relutância? Os Parâmetros Curriculares Nacionais (BRASIL/SEMTEC, 2002) são contemplados no que se refere à Pluralidade Cultural e Orientação Sexual? O Estatuto da Criança e do Adolescente (ECA) é respeitado?

Tais interrogaçóes nortearam a pesquisa, de abordagem qualitativa, realizada em uma escola pública do município de Sáo Paulo que tem grande afluência de alunos imigrantes e descendentes de imigrantes bolivianos. Esse fato justificou sua realização particularizada nas presumíveis discriminaçóes e prevençóes dirigidas ao alunado específico. Os objetivos gerais concentraram-se (1) nos possíveis atravessamentos subjetivos no ensino, na aprendizagem e na formação discente; e (2) na violação dos direitos das crianças e adolescentes. Já os específicos foram: a) observação e a análise das relaçóes interpessoal e educativa entre docentes e alunos bolivianos e descendentes de bolivianos e entre estes e os não bolivianos do Ensino Fundamental II, dos $8^{\circ}$ e $9^{\circ}$ a nos em sala de aula de professores colaboradores e nas dependências escolares comuns; b) identificação de ocorrências de negligência, discriminação e/ou opressão; c) verificação de cumprimento dos PCN, do ECA, da Declaraçáo Universal sobre a Diversidade Cultural (Unesco) e da Lei de Migração quanto à formação e ao respeito por docentes e membros da comunidade escolar; e d) a verificação do desempenho estudantil dos bolivianos e descendentes.

Os procedimentos metodológicos convergiram em observaçóes sistemáticas de aulas, reuniôes de Hora Trabalho Pedagógico Coletivo 
(HTPC) e de pais, e das áreas comuns como pátios, refeitório e corredores internos.

\section{A escola, os alunos e os colaboradores}

A escola selecionada para a pesquisa pertence à Diretoria Regional Centro e atende a aproximadamente 1.500 alunos, nos períodos diurno e vespertino. É considerada de alta vulnerabilidade porque se encontra em região de pequenos hotéis e comércios fixos e flutuantes que conferem ao entorno intensa movimentação de pessoas e de veículos. Muitos estabelecimentos, formais ou informais, empregam ou aliciam adolescentes discentes como mão de obra barata. Segundo informação do Projeto Político Pedagógico, $40 \%$ do total de alunos trabalham para auxiliar suas famílias e permanecem nesse ambiente suscetível, onde atua o tráfico de drogas lícitas e ilícitas. Há uma preocupação institucional constante com a possibilidade de introdução e consumo de substâncias viciantes, combatida por meio de palestras e rodas de conversas.

Os contatos iniciais com a coordenação pedagógica ocorreram no final de 2017. A apresentação dos procedimentos se deu na primeira hora de trabalho pedagógico coletivo do Ensino Fundamental II de 2018, da qual participaram 12 docentes de diversas disciplinas; dois destes permitiram a presença da pesquisadora em suas aulas.

A limitada aceitação, em classe, de um estranho com postura observacional pode engendrar desinteresse e desconforto nos professores, porquanto a ideia vigente é de que serão extraídos, unicamente, elementos negativos da regência, das atitudes e das condutas. Em certo sentido a suspeita é compreensível, pois situaçôes constrangedoras e/ou intimidadoras podem ocorrer, a depender da posição e do estilo assumidos pelos pesquisadores, como no caso de uma etnografia da classe direcionada à atuação docente (ANDRÉ, 1995). A abordagem metodológica utilizada aproxima-se de uma antropologia escolar, em que se busca entender as relaçóes sociais e culturais (CAMPOS, 2007) estabelecidas em classe e fora dela, sem a intenção de julgamentos.

Acordados os dias e os horários das aulas com os docentes colaboradores - doravante nomeados Docente A (DA), incumbido de uma 
disciplina teórica, e Docente B (DB), de uma prática -, o pesquisador esteve presente por 22 horas e seis minutos em posição observacional. Antes do início das atividades, os(as) alunos(as) foram consultados(as) sobre a permanência da pesquisadora nas duas turmas e informados que não haveria qualquer tipo de interferência, tampouco integração com os grupos (GERHARDT; SILVEIRA, 2009). Com a concordância da maioria, apresentou-se o escopo da pesquisa.

As turmas contavam com um número variável de 25 a 30 alunos(as) adolescentes, com ingressos e abandonos frequentes. Estão matriculados(as) no $8^{\circ}$ ano oito bolivianos/descendentes, sendo cinco meninas e três meninos; e no ${ }^{\circ}$ o são quatro, três garotas e um rapaz. $\mathrm{O}$ número restrito não foi impedimento para as análises e apreensão dos eventos interpessoais escolares dado o caráter qualitativo empregado.

Os alunos do 8 ano, nas aulas do DA, espalham-se pela classe em grupos de afinidades, e da metade da sala para o fundo sentam-se os não bolivianos - no lado direito as meninas e do esquerdo os meninos. Os bolivianos e descendentes, por sua vez, colocam-se do centro para a frente e nas fileiras próximas ao quadro negro, em uma notável separação entre uns e outros, com prejuízo acentuado das relaçóes comunicacional e pessoal, bem como da formação e construção educacional e cultural, pois não há diálogo entre os dois grupos. A única exceção é uma garota que está integrada às não bolivianas.

No $9^{\circ}$ ano, ainda com DA, a situação é semelhante quanto ao posicionamento em sala e à comunicação. Os bolivianos/descendentes são três meninas e um rapaz, que se colocam apartados. Duas delas têm alta frequência nas aulas e interagem com uma aluna não boliviana que apresenta obesidade mórbida e denota certa violência e agressividade com os colegas náo bolivianos. $\mathrm{O}$ rapaz senta-se sozinho, permanece cabisbaixo, realizando as atividades sem levantar a cabeça. Essa posição é a mesma da última boliviana, que, quando presente, conserva-se debruçada sobre a carteira, dormindo e sem produçáo alguma.

O planejamento do DA foi seguido nas duas turmas com as mesmas estratégias didáticas, compostas de seminários temáticos com recursos obtidos em bibliografias, semanários e na rede mundial, e debates entre grupos com perguntas e respostas, com atribuiçôes de pontos positivos para os acertos e negativos para os comportamentos indisciplinados e desatentos. 
O docente complementava as exposiçôes orais com indicaçóes de outras referências físicas e/ou virtuais, correção de enganos e apreciação da qualidade, mas não se estendia em aulas expositivas. Esse formato chamava a atençáo de parcela do alunado. A verificação do cumprimento de tarefas era ocasional e as ausências computadas diariamente, com a advertência da quantidade permitida para aprovação.

Em certas situaçôes, os alunos eram aconselhados a seguir normas de convívio, respeito mútuo e cuidado pessoal. A título de exemplo, DA chamou a atenção da sala, sem citar nomes, para o vestuário extravagante e chamativo de algumas jovens não bolivianas, que poderiam atrair a atenção de pessoas maledicentes, e em outra ocasião, quando uma aluna ingressou na escola embriagada, sequela de uma agressáo sexual. Não houve absenteísmo e algumas suspensóes de aulas advieram em razão de reuniōes extras ou eventos programados.

As aulas do DB, também no 9a ano, restringiam-se a grupos de jogos: vôlei, queimada e futebol. As duas bolivianas/descendentes ficavam em outro recinto esportivo onde não eram realizadas atividades físicas, sem contato com os(as) demais, apenas com a citada aluna não boliviana. $\mathrm{O}$ rapaz, nas aulas iniciais do semestre, mantinha-se observando o futebol, fato logo anotado pelo DB, que pediu sua inserção e foi atendido nas aulas subsequentes. Houve uma única licença médica docente e as interrupçóes pelos mesmos motivos do DA, já que as aulas eram no mesmo dia da semana.

$\mathrm{O}$ intervalo entre as aulas do DA e do DB era o momento em que os(as) alunos(as) recebiam a refeição do dia, que para muitos era a primeira. Nesse período e após a alimentação os(as) bolivianos/descendentes reuniam-se em pequenos grupos e isolavam-se em espaços mais afastados ou naqueles em que os(as) não bolivianos(as) não frequentavam, sempre em conversas reservadas, dividindo lanches ou apenas aguardando o reinício das aulas, mas sem contato com os demais.

O encontro de sujeitos de diferentes culturas tensiona as relações, permite a descoberta pessoal e do outro e pode abrir espaço para o novo. No que se refere à escola, pode criar as condiçóes favoráveis para aquilo que Freire caracteriza como outra pedagogia, na qual o sujeito tem o direito e o domínio da palavra para expressar sua experiência por meio do diálogo. 


\section{Adolescência, relaçóes interpessoais e desempenhos}

As relações interpessoais entre alunos adolescentes e docentes estão, em geral, pautadas em situações e compreensôes específicas que se encarregam de delimitar quem e como são os que vivem "[...] entre o casulo da infância e a integração ao mundo adulto." (MORIN, 2018, p. 11) Destacam-se entre elas as reguladas pela literatura clássica contemporânea especializada, que estima esse tempo, invariável e inalteradamente, conflituoso, tensivo e impactante (ERIKSON, 1972; ABERASTURY; KNOBEL, 1985; ABERASTURY, 1990), e as moderadas em vivências cotidianas, que demonstram ser esse um momento crítico permeado por episódios voluntariosos e provocadores, como descreveu Aristóteles em Arte retórica e arte póetica (s/d, p. 127): "Os jovens [...] são propensos aos desejos e capazes de fazer o que desejam. Entre os desejos do corpo, a principal inclinação é para os desejos amorosos, e não conseguem dominá-los. [...] São coléricos, irritadiços e geralmente deixam-se arrastar por impulsos.” Shakespeare, em Um conto de inverno (1610-11, n. p., cena III), quando a personagem do Pastor declara: "Desejara que náo houvesse idade entre dezesseis e vinte e três anos, ou que a mocidade dormisse todo esse tempo, que só é ocupado em deixar com filhos as raparigas, aborrecer os velhos, roubar e provocar brigas."

Como se pode perceber, sob essas óticas não há escapatória: os desenvolvimentos físico e psicológico estão comprometidos e acentuam o surgimento de atitudes inaceitáveis derivadas de transformaçóes corporais alusivas ao crescimento, à sexualidade e ansiedades associadas. A tendência da comunidade escolar é seguir esse padrão e associar o sujeito adolescente como alguém que reflete suas inconformidades pessoais e sociais no meio, no círculo de convivência e, quando na escola, em seus professores.

Entende-se que há certa imprecisão nessas generalizaçôes ao se prejulgar como inconvenientes e inadequados todos os adolescentes, pois, como muitos adultos reivindicarão, não foram violentos, desrespeitosos, abusados, inoportunos, aborrecidos ou indisciplinados na escola ou longe dela no decorrer desse ciclo, confirmando a tese de sobre/ determinação dessa etapa (DIAS, 2001). Oportuno adicionar a visão de Winnicott (1995), que ponderava ser a passagem do tempo essencial à adolescência, por facilitar a adaptação ao mundo adulto e às regras 
sociais. Para o autor, a reação nociva emerge dos que são incapazes de suportar o prazo de duração dessa estação que conduz ao amadurecimento e de perceber que muitas das proezas juvenis não congregam descaminhos antissociais.

As observações das turmas em tela mostraram que é possível distinguir adolescentes no que diz respeito a previsóes ou prognósticos que impactam profecias autorrealizadoras (PATTO, 1992; DIAS, 2015), divergir de categorizaçôes definidoras e estáticas e das identidades-mito impingidas pelo mundo externo (CIAMPA, 1993), visto que inúmeros alunos, independentemente da origem, comportavam-se em consonância com as regras socioeducacionais. $\mathrm{O}$ adolescente, como sujeito em desenvolvimento, não é prisioneiro de profecias autorrealizadoras ou de estigmas. Seu jeito de agir está, por vezes, circunscrito a determinadas situaçóes. O sujeito é um ser complexo, afetado por múltiplos fatores, e dificilmente podemos ter uma previsão tão assertiva e exata sobre ele. A vida não é estática, é dinâmica; o ser humano é sempre um projeto em construção, não é, é um vir a ser. $\mathrm{O}$ sujeito não existe de forma isolada, é sempre o sujeito na relação, eu e você, eu e eles... (cf. SOUZA NETO, 2001)

Os procederes dos bolivianos e descendentes sobressaíam-se à medida que a maioria era assídua, sempre uniformizada, cortês, estável, disciplinada, silente, cumpridora de deveres, recolhida em seu mundo e introvertida, acedendo à ideia de que nem todos os jovens têm dificuldades de convivência e sociabilidade. A despeito disso, nem todos os discentes eram tranquilos e respeitosos, já que muitos, em especial os não bolivianos, reagiam e abonavam as predicações e os regramentos com brutalidades ou impetuosidades; negavam-se a cumprir as tarefas diárias, estudar, silenciar nos momentos necessários, compatibilizando-se com as definiçóes da etapa conflituosa, crítica e tensiva.

Duas particularidades dos bolivianos/descendentes predominavam: o recolhimento e a introversão. A primeira compreendida como refúgio e/ ou asilo protetivo contra ameaças efetivas ou ideadas; a segunda, quando a energia psíquica é dirigida para o interior como resultante de um desvio "[...] da realidade, que perdeu o seu valor para o indivíduo devido à frustração obstinada que dela provém, e volta-se para a vida fantasmática, onde cria novas formaçóes de desejo e reanima os traços anteriores de formação de desejo já esquecidos." (LAPLANCHE; PONTALIS, 1988, p. 
326) As circunstâncias existenciais dos bolivianos/ descendentes levam a pressupor que buscavam produzir e revigorar desejos, novos ou antigos, na tentativa de banir as decepçóes e os desapontamentos relativos ao preconceito e à discriminação dos quais são vítimas.

A formação do sujeito é tecida numa via de mão dupla, pela qual trafegam elementos da subjetividade e da objetividade. O cotidiano e a prática escolar dessas crianças, bolivianas ou não, abrem uma clareira para a percepçáo de que os processos subjetivo e objetivo ajudam na apropriação do mundo. Esse mecanismo de apropriação e a capacidade de sonhar permitem superar ou equacionar as contradiçôes vividas, mesmo que em muitas situaçóes ou momentos o sofrimento não seja inteligível. A cultura colonizadora pode ver de forma preconceituosa os diferentes procedimentos. Isso, no fundo, é uma forma de não aceitar o outro.

Cada sujeito se constitui a partir de uma biografia, e ao estabelecer relaçóes com pessoas, grupos e estruturas vê-se impelido a repensar sua vida. Talvez seja esse um dos atos mais importantes da educação. $\mathrm{O}$ jeito de o boliviano e o brasileiro se colocarem no mundo e na escola é diferente. De um lado, é definido pela marca da cultura; de outro, pela situação, uma vez que o adolescente imigrante em questão está fora do seu habitat. Algumas atitudes e comportamentos são sinais de pedido de socorro ou de sobrevivência. Quando chega a determinado local um grupo de hábitos, valores, tom da pele, linguagem, educação, religiáo e outros elementos culturais diferentes, cria-se nele uma imagem dos membros desse grupo. O novo grupo que chega, por sua vez, produz uma autoimagem. Ambas as imagens se afetam e encontram eco uma na outra. Tal situação pode estabelecer um estigma. Sem dúvida, os indivíduos sofrem um grau de coerção, seja ou não verbalizado, que às vezes dificulta às pessoas interagirem entre si. Podemos encontrar essa perspectiva em Norberto Elias, quando reflete sobre os velhos e novos moradores de uma comunidade. "Nesse sentido, os recém-chegados foram vividos como uma ameaça pelos antigos moradores.” (ELIAS, 2000, p. 167) Quando os novos sujeitos chegam à escola, cria-se certa tensão entre professores, alunos e na direção; em síntese, com a cultura escolar.

Bourdieu (1998, p. 11) descreveu a posiçáo e o lugar ocupados pelos imigrantes em qualquer localidade de destino como atopos, afirmando que são 
[...] "pessoas descoladas", privadas de um lugar apropriado no espaço social e de lugar marcado nas classificaçôes sociais. Como Sócrates, o imigrante é atopos, sem lugar, deslocado, inclassificável. [...] Nem cidadão nem estrangeiro, nem totalmente do lado do Mesmo, nem totalmente do lado do Outro, o "imigrante" situa-se nesse lugar "bastardo" de que Platão também fala, a fronteira entre o ser e o não-ser social (grifo do autor).

Se o imigrante é atopos, por outro lado, pela ótica de Elias (2000), ele está em busca de construir um novo lugar. No espaço social escolar, os bolivianos/descendentes não tinham lugar. Encolhiam-se em lugares pouco frequentados pelos náo bolivianos, embaixo da escada, nos bancos contíguos aos lavatórios ou na quadra esportiva desativada e descoberta, isolados da maioria, talvez na tentativa de se preservarem, resguardarem raízes e tradiçôes, ou porque se sentiam "pessoas descoladas" e não encontravam um ambiente comum, próprio e legítimo. De uma ou de outra forma, estavam em busca de reconhecimento.

Na formulação de Bourdieu (2001, p. 485), esse lugar "bastardo" afigura-se também aos "marginalizados de dentro", obrigados a uma permanente oscilação entre "[...] a submissão ansiosa e a revolta impotente", como denominou o autor ao examinar as migraçóes e a escola, esta designada "[...] como um engodo e fonte de uma imensa decepção coletiva: uma espécie de terra prometida, sempre igual no horizonte, que recua à medida que nos aproximamos dela." (op. cit., 483) As demonstrações atitudinais absorvidas dos bolivianos e descendentes sintetizavam essa marginalização, pelo discernimento e pelas zonas espúrias ocupadas, expondo o preconceito suportado. As tensôes, nesse caso, são múltiplas e têm múltiplas origens, questionam a todos e requerem a construção de um novo tecido social e de uma nova postura pedagógica, uma nova cultura escolar.

Jodelet (2001) concebeu o preconceito pelas perspectivas cognitiva e afetiva. A cognitiva, explicitada nos conteúdos e afirmaçóes dirigidas ao objetivo; e a afetiva vinculada às emoçóes e às representaçóes desabonadoras ou favoráveis. Entretanto, essas perspectivas náo são mutuamente exclusivas, em virtude da infiltração subjetiva nas elaborações racionais que obstruem ou impedem uma apreensão isenta das vivências e experiências 
(cf. MORIN, 2005a; DIAS, 2015; MARTINEZ; SCOZ; CASTANHO, 2012; SOUZA NETO, 1997). Desse modo, compreende-se a conotação emocional como fundante das relaçóes interpessoais, com papel preponderante nos processos migratórios, pois comumente seus integrantes são absorvidos como invasores e desencadeadores de problemas de cunho social importantes, como usurpação do emprego de nativos, estabilização de alojamentos temporários, descaso com a saúde etc. (CANDAU, 2011)

$\mathrm{Na}$ escola estudada, o preconceito docente extraído das aulas observadas e das horas de trabalho pedagógico coletivo revestia-se, pela perspectiva cognitiva, na disciplinarização e no bom desempenho nos estudos, diferenciando bolivianos e descendentes como os melhores alunos. E pela ótica afetiva, em momentos predominados por desclassificaçóes e descréditos ancorados na origem, na naturalidade e na cultura bolivianas, com força suficiente para avalizar a introversão e o recolhimento, que, acrescidos da adolescência, se aparentavam intransponíveis.

A ambivalência e a ambiguidade dos professores coincidiram com a dialógica sapiens/demens, gerada, respectivamente, na racionalidade e no conhecimento, no desatino, na odiosidade e naquilo "[...] que os gregos chamavam a Hybris, a desmedida.” (MORIN, 2005b, p. 10) O entrelaçamento e a complementaridade entre sabedoria e loucura expóe características humanas que congregam saberes, sensatezes e responsabilidades de um lado, e brutalidades e agressividades, ${ }^{3}$ de outro.

Uma situação paradigmática dos sentimentos embrenhados na racionalidade pode ser validada pela ausência, por alguns dias, de uma aluna imigrante e sua embriaguez quando do seu retorno. Foi relatada a ocorrência de assédio sexual pelo seu pai, contestada pela mãe e o irmão, que atestavam o contrário: a garota o assediando. Entre verdades e ilaçôes, e sem um distanciamento fenomenológico necessário à análise, os docentes e a Coordenação Pedagógica $(\mathrm{CP})$ atrelaram o fato à procedência, aos costumes bolivianos e à juventude, concedendo uma apreciação dúbia da cena que responsabilizava pai, filha e a cultura. De modo distinto, os docentes colaboradores mostraram-se surpresos, preocupados e inconformados com as declaraçóes da família e o sofrimento da jovem.

Em relação à compreensáo do envolvimento cultural ao consumo de álcool, a pesquisa desenvolvida por Fernandez (2015, p. 138) apresenta o depoimento de um imigrante boliviano que assegurava ser o álcool "[...] 
o lado cultural da bebida. Na Bolívia, o pessoal bebe muito, é um reflexo do início da conquista espanhola também, porque as pessoas que ficaram e colonizaram a América eram assassinos, mercenários, bandidos, castigados [...]" Assinala-se que a explicação para o abuso alcoólico e a drogadição em momentos de lazer assenta-se no alívio e no consolo pelo enclausuramento do trabalho escravizante em oficinas de costura. Contudo, expóe um quadro contraproducente da comunidade, atinge crianças e adolescentes em idade escolar, não se justifica e sugere que os bolivianos e descendentes são incapazes de absorver as agruras do cotidiano e necessitam de subterfúgios para sustentá-las.

Outra questão tratada como cultural na escola e comentada por alguns professores diz respeito às queixas de os bolivianos e descendentes exalarem odores desagradáveis por falta de higiene, embora não se tenha registrado qualquer situação assemelhada, já que se apresentavam sempre asseados e vestidos com esmero. É preciso enfatizar que esses bolivianos e descendentes estão atrelados à dependência de pagamentos extras para banhos adicionais, em razão de viverem em moradias encortiçadas e precárias, que racionam as duchas a uma por dia.

Admite-se que se tenham expandido na Bolívia imprintings acerca do alcoolismo e do asseio, aos poucos transformados em sinais típicos e conferidos "[...] primeiro, pela cultura familiar e, depois, pela cultura social, que se mantém na vida adulta.” (MORIN, 2005a, p. 302) A aprendizagem pode ter encaminhado parte da população à crença de costumes tradicionais que, nas transferências de localidades, foram carregados junto com "[...] las estructuras sociales, politicas y mentales de su sociedade." (SAYAD, 2010, p. 22)

Morin (2005a, p. 165) define cultura como “[...] a emergência maior da sociedade humana. Cada cultura concentra um duplo capital: por um lado, um capital cognitivo e técnico (práticas, saberes, savoir-faire, regras); por outro lado, um capital mitológico e ritual (crenças, normas, interdiçôes, valores)." É organizada e ordenada pela linguagem e embute aprendizados conquistados por intermédio de capacidades, experiências, história e mitos, em uma dinâmica recursiva na qual sua produção torna-se produtora e geradora do que produz, estabelecendo entre cultura e sociedade uma causação mútua. (op. cit, 2002) 
O preconceito, na esteira dos imprintings, agrega-se às personalidades e pode ser visibilizado em hostilidades, indiferenças e/ou intransigências, como expressão de um barbarismo antropológico, com potencial para consolidar princípios e opinióes, cristalizar certezas e fantasias e materializar-se em monoculturas homogeneizantes que germinam rupturas significativas entre migrantes e nativos (cf. MORIN, 2005b; CANDAU, 2011).

O cotidiano escolar ou a cultura escolar expressa, ou demonstra, por um lado, que a sociedade e as instituiçóes produzem o ser humano; por outro, também o ser humano gera formas institucionais. Com base em Morin (2005a), podemos entender que o sujeito se constrói por movimentos complexos de interação entre a objetividade e a subjetividade, o sapiens e o demens, o cognitivo e o emocional, as estruturas sociais e psíquicas. As pedagogias mais atuais tendem a conceber os adolescentes como feixes de pulsão e de imaginação. A escola tem como intencionalidade promover e despertar no educando a capacidade de comandar e de ser comandado, de aprender a aprender, de aprender a descobrir, de aprender a inventar, de aprender a extrair energia das adversidades. $\mathrm{O}$ encontro dos adolescentes bolivianos descendentes com os não bolivianos possibilita um processo de transformação, não só dos sujeitos, mas sobretudo da cultura escolar.

$\mathrm{Na}$ escola, à primeira vista a indiferença era a principal manifestação dos professores, porque os alunos bolivianos e descendentes causavam pouquíssimos transtornos. Entretanto, uma perscrutação atenta expunha uma ambivalência emocional desqualificadora, traduzida em descortesias, sectarismos e rigidezes de pensamento que demonstravam a impregnação de valores e julgamentos depreciadores dirigidos a adolescentes imigrantes e descendentes, apesar de inúmeros serem brasileiros. Revestidas de tolerâncias, tais atitudes, supostamente, espelhavam a falsa permissão de presenças indesejáveis.

Constatou-se, ainda, que o vocábulo boliviano se firmou como insulto e ofensa em momentos de violência, zombaria e ironia, cruzando e sulcando as inter-relaçôes, os dispositivos legais e as personalidades em constituição de adolescentes, além de propagar a dubiedade da nacionalidade, pois, se averiguada pela aparência, os descendentes são identificados como bolivianos, quando na verdade são brasileiros. 
É necessário salientar que os bolivianos e descendentes também discriminam e debocham da própria coletividade boliviana, como detectado e declarado por um professor em uma hora de trabalho pedagógico coletivo, chamando a atenção para situaçóes de bullying e preconceito, consequentes do local de nascimento na Bolívia, a forma como lutam pela sobrevivência e por náo dominarem o português. Esse movimento foi denominado por Mármora (1995, apud FERNANDEZ, 2015) como endofóbico, isto é, quando se rejeitam os indivíduos do próprio grupo como resultado de um processo de exclusão e não aceitação. Infere-se que a proximidade entre as jovens bolivianas descendentes e uma garota obesa se baseava nos elementos rejeição, segregação e endofobia que as unia emocionalmente, facilitava o retraimento e expulsava os demais, pois as bolivianas descendentes não se comunicavam com ninguém mais, não obstante o assujeitamento a que estavam submetidas.

O desempenho escolar dos bolivianos descendentes na disciplina teórica observada era superior ao dos não bolivianos, seja na apresentação oral e escrita de trabalhos, na elaboração de pesquisas e, em particular, na leitura, reconhecida pela precisão verbal sem tropeços, falhas de pronúncia ou sotaques. Contrariamente, o desempenho de não bolivianos mostrou-se bem menos qualificado e problemático, pois as dificuldades apresentadas por alunos de $8^{\circ}$ ano surpreenderam pela incompreensão do significado e pela verbalização entrecortada.

Os estudos e compromissos escolares tinham um sentido específico para os bolivianos descendentes e exigiam deles dedicação, obrigações, acordos, pactos cumpridos e concentração, que desembocavam em recolhimento e introversão. Essas eram as principais facetas visíveis dos bolivianos e descendentes, que ainda incluíam escassos diálogos com professores ou colegas e concentração no exercício das atividades designadas, como identificou Soares (2015) em investigação dirigida à comunidade boliviana.

Os acertos e tratados acordados em aula parecem ter pouca importância para os não bolivianos em razão de as tarefas nem sempre serem concretizadas, a disciplina descaracterizada, a atenção permanecer inconstante e a algazarra persistente, levando o DA a exigir silêncio e ameaçar os inquietos com a convocação dos responsáveis e rebaixamento de notas. Ainda assim, eles transmitem a impressão de se sentirem mais livres e des- 
contraídos, e com liberdade para emitir sentidos e sentimentos à revelia dos professores.

Diante desse cenário, a instituição escolar mostra-se em descompasso com a legislação vigente. Os PCNs, a Declaração Universal sobre a Diversidade Cultural e a Lei das Migraçóes foram rompidos no reconhecimento da diversidade, como objeto intrínseco à identidade brasileira, e na superação de açóes discriminatórias de comunidades e grupos que integram a sociedade. A assunção do alunado a comportamentos solidários foi escassa, no entanto expressiva no $9^{\circ}$ ano, com o convite semanal de um boliviano para a composição do time de futebol e a relaçáo de cumplicidade entre as alunas bolivianas/descendentes e a não boliviana. No $8^{\circ}$ ano, o distanciamento foi profundo e o recolhimento dos alunos bolivianos descendentes bastante visível, com somente uma aluna participando do convívio com os não bolivianos. Nas duas turmas a discriminação estava atada às separações entre os grupos, na frente e no fundo da sala. A participação nas festas comemorativas foi discretíssima, com somente um integrando a equipe de dança, comunicando assim a clivagem.

Os eixos estruturantes da educaçáo, norteados pelos princípios da dignidade da pessoa humana, igualdade de direitos com vistas à equidade, à participação e à corresponsabilidade pela vida social, na manutenção e amplificação da democracia foram considerados pelos membros da direção e professorado sem, contudo, uma direção específica aos alunos bolivianos descendentes.

\section{$4 \quad$ Finalizando}

A pesquisa nos ajuda a compreender que é preciso pensar a educação no contexto situacional e relacional do sujeito, e perceber como ele age e reage na busca da liberdade e do reconhecimento. As pessoas praticam suas açóes e condutas não de forma subjetivista e abstrata, mas no campo do vivido, das realidades vitais. Ninguém nasce odiando ou amando, matando ou roubando, aceitando ou rejeitando. Até os dias atuais, nenhuma literatura descreve o nascimento de uma criança previamente 'armada' contra os demais. Suas açôes e reações estão influenciadas pelo contexto. A contraposição entre personalidade e sociedade é uma abstração vazia. 
Não pode existir um sujeito independente da sociedade ou vice-versa. As formas de estranhamento atingem e movem os indivíduos e fazem deles seres sociais.

Acreditamos que a educação social pode ajudar na mediação do encontro entre duas culturas na escola. A própria construção da política dos direitos humanos no Brasil altera o campo relacional, e todos necessitam aprender a conviver dentro dessa nova lógica. "Decorre daqui que a educação social, sendo concebida como um processo de interaçáo entre pessoas que livremente decidem levar a cabo, de modo consensual, suas respectivas intencionalidades, é uma construção livre." (BAPTISTA, 2004, p. 56) O encontro entre culturas, quando mediado por uma pedagogia fundada nos direitos humanos ou libertadora, busca dirimir as formas de rejeição, de exclusão, de humilhação.

Conflitos entre culturas no interior da escola apontam para a necessidade da humanizaçáo da escola e da desconstruçáo de uma pedagogia de humilhação, que constitui hoje boa parte da cultura escolar (cf. SOUZA NETO, 2001; SILVA, R.; GRACIANI, M. S. S., 2017). Uma questão preponderante nas relaçóes interpessoais é o atravessamento subjetivo e seu potencial de interferência na racionalidade e, por consequência, no ensino e na aprendizagem. As relaçóes entre alunos aproximavam-se das estabelecidas entre pares que se afastam ou se aproximam por afinidades, apreços, identificaçóes, diferenças, inimizades, impondo segregação e recolhimento aos alunos bolivianos e descendentes.

Em relação aos docentes, por mais clareza que tenham sobre seu papel educacional, seus afetos penetraram, rumorosa ou silenciosamente, em condutas, açóes, atitudes, o que compromete o trabalho. Foi isso que se depreendeu das observações: sentimentos transpassando inter-relaçóes laborais e pessoais, sem prejuízo ou violação de direitos, mas com certo descuido em relaçáo aos alunos bolivianos e descendentes, porque, em tese, não demandavam atenção por serem bons alunos. A origem interferiu nos julgamentos e ponderaçôes.

Uma saída para esse estado de coisas é um projeto consistente junto à coletividade escolar, já que algumas açôes eram propostas, por meio de reunióes dialogadas, com vistas ao reconhecimento do outro, à conscientização e criação de meios e maneiras de transposição de comportamentos depreciativos e/ou desqualificadores. 


\section{Notas}

${ }^{1}$ Parte deste artigo foi extraída do relatório final de pesquisa de pós-doutorado de Elaine T. Dal Mas Dias, sob a supervisão do Prof. Dr. João Clemente de Souza Neto, no Programa de PósGraduaçấo em Educação, Arte e História da Cultura da Universidade Presbiteriana Mackenzie (UPM), com anuência do Comitê de Ética em Pesquisa da Universidade Nove de Julho (UNINOVE) - CAAE n. 86682518.6.00005511. Este trabalho foi também apresentado no VI Congresso Internacional de Pedagogia Social, em 2018, realizado na UPM, além de servir como base para o artigo "Multiculturalismo em educação: o atendimento escolar de alunos bolivianos e descendentes. Dialogia, São Paulo, n. 29, p. 83-94, mai./ago. 2018. Disponível em: https://doi.org/10.5585/Dialogia.n29.8802.

${ }^{2}$ Entende-se por imigração o "movimento de pessoas ou de grupos humanos, provenientes de outras áreas, que entram em determinado país com o intuito de permanecer definitivamente ou por período de tempo relativamente longo." (Instituto de Migraçóes e Direitos Humanas. Disponível em http://www.migrante.org.br/index.php/glossario).

${ }^{3}$ Cf. Darcy Ribeiro (1995).

\section{Referências}

ABERASTURY, A.; KNOBEL, M. Adolescência normal. Trad. Suzana M. G. Ballve. Porto Alegre: Artes Médicas, 1985.

ABERASTURY et al. Adolescência. Trad. Ruth Cabral. Porto Alegre: Artes Médicas, 1990. (Doutorado em Educação Física). Universidade Estadual de Campinas, Faculdade de Educação Física, Campinas (SP), 2011.

ANDRÉ, M. E. D. Afonso de. Etnografia da prática escolar. Campinas: Papirus, 1995.

ARISTÓTELES. Arte retórica e arte poética. Trad. Antônio P. de Carvalho. Rio de Janeiro: Ediouro, [1970?].

BAPTISTA, I.; CARVALHO, A. D. Educação social, fundamentos e estratégias. Portugal: Porto Editora, 2004.

BOURDIEU, P. Prefácio: um analista do inconsciente. In: SAYAD, A. A imigração ou os paradoxos da alteridade. Trad. Cristina Murachco. São Paulo: Edusp, 1998.

BOURDIEU, P.; CHAMPAGE. P. Os excluídos do interior. In: BOURDIEU, P. et al. A miséria do mundo. Trad. Mateus S. S. Azevedo et al., 4. ed. Petrópolis: Vozes, 2001.

BRASIL/SEMTEC. PCN+Ensino Médio: Orientaçóes educacionais complementares aos Parâmetros Curriculares Nacionais, v. 1: Linguagem, códigos e suas tecnologias. Brasília/DF: MEC/SEMTEC, 2002. Disponível em: <portal.mec.gov.br/seb/arquivos/ pdf/02Linguagens.pdf $>$. Acesso em: 18 jan. 2016. 
CIAMPA, A. da C. A estória do Severino e a história da Severina: um ensaio de psicologia social. São Paulo: Brasiliense, 1993.

CANDAU, V. M. Multiculturalismo e educação: Desafios para a prática pedagógica. In: CANDAU, V. M.; MOREIRA, F. A. (orgs). Multiculturalismo: diferenças culturais e práticas pedagógicas. 7. ed. Petrópolis: Vozes, 2011.

CLARO, C. de A. B. As migraçôes internacionais no Brasil sob uma perspectiva jurídica: Análise da legislação brasileira sobre estrangeiros entre os séculos XIX e XXI. Cadernos do Observatório das Migraçóes Internacionais. Brasília, v. 1, n. 1, p. 119-210, 2015.

DIAS, E. T. D. M. Comunidade de aprendizagem: ecologia da ação e profecias autorrelizadoras. In: HENNING, L. M. P. Filosofia e educaçâo: Caminhos cruzados. Curitiba: Appris, 2015.

DIAS, E. T. D. M. Adolescência: Entre o passado e o futuro, a experiência. Tese (Doutorado em Psicologia). São Paulo: Instituto de Psicologia, Universidade de São Paulo, 2001.

DIAS, E. T. D. M.; SOUZA NETO, J. C. Multiculturalismo em educação: O atendimento escolar de alunos bolivianos e descendentes. Dialogia, São Paulo, n. 29, p. 83-94, maio/ago. 2018. Disponível em: <https://doi.org/10.5585/Dialogia.n29.8802>. Acesso em: 18 fev. 2019.

DOU - Diário Oficial da União, 25 maio 2017, p. 1. Acesso em: 20 mar 2018

ELIAS, N.; SCOTSON, J. L. Os estabelecidos e os outsiders. Rio de Janeiro: Zahar, 2000.

ERIKSON, E. H. Identidade, juventude e crise. Trad. Álvaro Cabral. Rio de Janeiro: Zahar, 1972.

FERNANDEZ, C. C. G. Entre dois países, sonhos e ilusôes: Trajetórias de el imigrantes bolivianos em São Paulo. Tese (Doutorado em História). São Paulo: Pontifícia Universidade Católica, 2015.

GERHARDT, T. E.; SILVEIRA, D. T. (orgs.) Métodos de pesquisa: planejamento e Gestão para o Desenvolvimento Rural da SEAD/UFRGS. Porto Alegre: Editora da UFRGS, 2009.

JODELET, D. Os processos psicossociais de exclusão. In: SAWAIA, B. As artimanhas da exclusão. Análises psicossociais e ética da desigualdade social. 2. ed. Petrópolis: Vozes, 2001.

LAPLANCHE, J.; PONTALI, J.-B. Vocabulário da psicanálise. Trad. Pedro Tamen. 10. ed. São Paulo: Martins Fontes, 1988. 
MARTINEZ, A. M.; SCOZ, B. J. L.; CASTANHO, M. I. S. (orgs.) Ensino e aprendizagem: a subjetividade em foco. Brasília: Liber Livro, 2012.

MORIN, E. O método 5: a humanidade da humanidade. Trad. Juremir da Silva. 3. ed. Porto Alegre: Sulina, 2005a.

MORIN, E. Cultura e barbárie europeias. Trad. Ana P. Viveiros. Lisboa: Instituto Piaget, 2005b.

MORIN, E. Prefácio à edição brasileira. In: MORIN, E.; LEFORT, C.;

CASTORIADIS, C. Maio de 68: A brecha. Trad. Anderson Lima da Silva, Martha Coletto Costa. São Paulo: Autonomia Literária, 2018.

PATTO, M. H. de S. A família pobre e a escola pública: Anotações sobre um desencontro. Psicologia USP, v. 3, n. 1/2, 1992.

RIBEIRO, D. O povo brasileiro, a formação e o sentido do Brasil. São Paulo: Cia. das Letras, 1995.

SAYAD, A. La doble ausência de las ilusiones del emigrado alos padecimentos delinmigrados. Barcelona: Ediciones UIB, 2010.

SHAKESPEARE, W. Um conto de inverno. Versão eBook. Disponível em: www.jahr. org. Acesso em: 16 jan. 2019.

SOARES, C. de F. Imigrantes e nacionais: um estudo sobre as relaçóes sociais em sala de aula. Dissertação (Mestrado em Educação), Pontifícia Universidade Católica de São Paulo, 2015.

SOUZA NETO, J. C. Mutaçóes da esfera pública. In: BAPTISTA, D. et al. Cidadania e Subjetividade. São Paulo: Imaginário, 1997, p. 73-121.

SOUZA NETO, J. C. Crianças e adolescentes abandonados, estratégias de sobrevivência. São Paulo: Expressáo e Arte, 2001.

SOUZA NETO, J. C; SILVA, R.; GRACIANI, M. S. S. Pedagogia social, a pesquisa em pedagogia social. São Paulo: Expressão e Arte, 2017.

WINNICOTT, D. D. Privação e delinquência. Trad. Álvaro Cabral. São Paulo: Martins Fontes, 1995.

Recebido em 24 fev. 2019 / Aprovado em 15 mar. 2019

Para referenciar este texto:

DIAS, E. T. D. M.; NETO, J. C. S. Diversidade cultural no espaço escolar: implicaçôes no ensino, na aprendizagem e nos processos de subjetivaçáo. EccoS Revista Científica, São Paulo, n. 48, p. 5I-70. jan./mar. 2019. Disponível em: <https:// doi.org/10.5585/EccoS.n48.12380>. 